\title{
A KÜLFÖLDI TŐKE SZEREPE A BUDAPESTI AGGLOMERÁCIÓS ÖVEZET FELDOLGOZÓ-IPARI TÉRSZERKEZETÉNEK KIALAKÍTÁSÁBAN
}

\author{
(The Role of Foreign Capital in Developing the Spatial Structure \\ of the Processing Industry in the Budapest Agglomeration Belt)
}

\section{SÁGI ZSOLT}

\section{Bevezetés}

A kilencvenes évtizedben a hazai gazdaság alapvető területi jellemzője a differenciálódás. A budapesti agglomeráció gazdaságának fejlődése, átalakulása napjaink Magyarországának egyik legszembetűnőbb, legdinamikusabb folyamata. A gazdasági aktivitás, az extenzív és intenzív fejlödést jellemző mutatók gyökeres változást jelentenek, amelyhez fogható gazdasági metamorfózist csak a hagyományos iparvidékek leépülése vagy az Észak-Dunántúl dinamizálódása jelent. Az agglomerációs övezet a gazdasági rendszerváltozás egyértelmủ nyertesének tekinthető. Az övezet gazdasági térszerkezete azonban nem homogén, sőt akkora különbségek adódhatnak, amelyek már megkérdőjelezhetik a terület - elsősorban fejlesztési szempontokat szem előtt tartó - elkülönítését, önállóságát. A rendszerváltás óta eltelt évek a társadalmi-gazdasági tér több dimenziójában új térstruktúrát alakítottak ki. Igaz ez nemcsak az agglomeráció központját jelentő fỏváros, hanem vizsgálatunk földrajzi terét képező agglomerációs övezet vonatkozásában is. Tanulmányunk csak az agglomerációs övezet gazdaságát veszi górcsö alá, bár tisztában vagyunk azzal a ténnyel, hogy a végeredmény nehezen értelmezhető az agglomeráció központjának figyelmen kívül hagyásával.

A külföldi tỏke beruházásainak jó része a tercier szektorban realizálódott. Sok szó esik manapság a tercier szektorról. Valóban, a legszembetủnőbb változások ebben az ágazatban zajlanak, elsősorban a kereskedelem, a szállítás, a gazdasági szolgáltatások terén. Ki ne vásárolt volna már egy Cora, Metro, Auchan avagy egy Tesco hiper-, szuper- és más jelzővel ellátott „,market”-ben? Több kiváló munka is megjelent e témában az utóbbi időben. Tanulmányunk egy másik gazdasági szektort - a posztindusztriális kor „vesztesét” - választotta vizsgálódásának középpontjába: a feldolgozóipart.

A külföldi tỏke térszerkezetét, az övezet feldolgozó-ipari térstruktúrájára gyakorolt hatását a Hoppenstedt Bonnier Magyarország közép- és nagyvállalatai (1999) címü cégkatalógusa, illetve közel ötven céginterjú alapjản próbáltuk megrajzolni. Konkrétan ez az 1998-as jegyzett alaptőke, az 1997-es éves bevétel és az 1998-ban foglalkoztatott munkaerő vizsgálatát ölelte fel. A Hoppenstedt kézikönyv számos cégnél nem adta meg a jegyzett alaptőke tulajdonosi szerkezetét és a három alapadat valamelyikét, ezért pótlólagos információkat is kellett szerezni. Bár a felmérés 
nem tekinthetö így teljes körünek és metodikailag is kifogásolható, de reprezentatív jellege alapul szolgálhat a folyamatok irányvonalának meglátására.

\section{A külföldi tökebefektetések hatása a magyar ipar általános helyzetére}

Az országos ipari termelés az 1989 és 1992 között lezajlott visszaesést követően 1993 óta növekszik, 1998-ban elérte a 14\%-ot, melynek következményeként a termelés volumene elérte a rendszerváltás elötti, 1989-es szintet. A termelés szerkezete, az iparágak, ágazatok aránya gyökeres változáson esett át. A válságból való kilábalásban és a szerkezet átalakulásában meghatározó szerepe volt a működőtőke beáramlásának. Néhány év alatt új, exportorientált iparágak és szakmakultúrák fejlődtek ki, kiemelkedően gyorsan fejlődött a személygépkocsi- és alkatrészgyártás, az elektronika és az informatika. A privatizáció során föként szakmai befektetők valamint a zöldmezős beruházások révén gyorsan nőtt a külföldi és vegyes tulajdonú vállalatok aránya. 1998-ra a feldolgozó-ipari vállalkozások 57\%-a külföldi tulajdonba került.

A kilencvenes évek elején a kisvállalkozások voltak a gazdasági növekedés hordozói, 1997-re viszont a 300 fö feletti nagyvállalatok vették át ezt a szerepet. Ezek lényegében a transznacionális vállalatokkal azonosíthatók. A feldolgozó-ipari beruházások 80\%-a külföldi érdekeltségú vállalkozásokban realizálódott.

Technológiai szintek szerint az átlagosnál erősebb a magyar ipar polarizáltsága. Az OECD átlagnál magasabb a fejlett (high-tech) ágazatok termelési és foglalkoztatottsági aránya, ugyanakkor rendkívül magas a fordista ágazatok (low-tech) aránya is. A multinacionális cégeknél folytatott ipari termelés zöme high-tech tevékenység. Míg 1992-ben a high-tech termékek aránya mindössze 2,8\% volt a magyar exportban, addig 1997-re ez az arány 13,8\%-ra nőtt.

Az ipar területi elhelyezkedésében a többi nemzetgazdasági ághoz hasonlóan a polarizálódás folyamatai játszódnak le. A kelet-nyugati dichotómia ugyan oldódni látszik (az utóbbi néhány évben tapasztalható, hogy a befogadóképesség - elsősorban a munkaerő oldaláról - telitődött a Dunántúlon, és a müködőtőke beruházás kezd szétterülni kelet felé), de az arányok harmonizálódásáról még messze nem beszélhetünk.

1997-ben a külföldi tőke a növekvő méretü behatolás szakaszában volt Magyarországon. 1997-ig a külföldi tökebefektetések 46\%-a érkezett a Központi Régióba (Budapest és Pest megye). A régió részaránya időben valamelyest csökkenő tendenciát mutatott. A külföldi tökeberuházások ágazati megoszlása is változott idöben. Az ipar részaránya az 1993-as 66\%-ról 1997-re 48\%-ra csökkent. Ebben az évben a feldolgozóiparon belül a külföldi tulajdonban lévő vállalatok az összes nettó árbevétel 70\%-át adták.

1997 végéig a zöldmezős ipari beruházások összege 3,05 milliárd dollárt tett ki, amely 220 projektből állt. 1997 végéig a hazánkba beruházott külföldi tőke 20\%-a zöldmezős ipari beruházás volt. A zöldmezős ipari beruházások országonkénti sorrendjét az USA vezeti Németország és Japán előtt. Az ipari projektek számát illetően 
Németország vezet az USA elött. Az amerikai befektetések általában nagyobb összegüek, föként multinacionális cégekről van szó. A német és az osztrák beruházók között számos kis- és középvállalkozás található. A beruházások összegéböl 70\%-kal Észak-Dunántúl részesedett, megelözve a 17\%-os részarányú Központi Régiót. Ugyanez a helyzet az ipari projektek számát illetően. 1997-ig 103 illetve 50 projekt kezdte meg müködését a fenti két területen. Észak-Dunántúl egyre növelte a részarányát a többi régióhoz képest.

Becslések szerint az elmúlt években az ipari termelés növekedésének négyötöde a zöldmezös külföldi befektetéseknek köszönhetö. Ez azt jelenti, hogy az ipari termelés területi szerkezetében mélyreható változások történtek. A dinamikus növekedés kizárólag 4-5 északnyugati megyére és Pestre koncentrálódik. Budapesten szám szerint nem jelentéktelen a beruházási projektek száma, de mind a befektetés összegében, mind a termelési értékben, mind az alkalmazottak számában nincs jelentős részesedése. Az összes zöldmezös külföldi ipari beruházás több mint $85 \%$-a a Nyugat- és Észak-Dunántúlra, valamint a Központi Régióba áramlott. Az országos jelentőségű aktivizálódó térségek közé sorolható Gödöllő térsége is. Jelentős zöldmezös beruházások történtek Veresegyház, Szada, Gödöllö, Budaörs, Törökbálint és Dunaharaszti településeken. A zöldmezös ipari beruházások révén létrejött új kapacitások 1997. évi árbevétele 700 milliárd forintot tett ki.

\section{A külföldi jegyzett tóke elhelyezkedése}

A Hoppenstedt cégkatalógusa (1999) alapján az agglomerációs övezetben található 350 alaptőke adattal is leírt feldolgozó-ipari cégböl (közép- és nagyvállalat) 85-ben van jelen külföldi tóke. A tisztán külföldi tulajdonú közép- és nagyvállalatok aránya - a megyei és országos analóg folyamatokhoz hasonlóan - nőtt az évek során. Jelenleg az övezetben 45 ilyen közepes- és nagyvállalat múködik, s az 50\%-os arányuk igen magas. Meg kell említenünk emellett, hogy sok vegyesvállalat tulajdonszerkezetében a hazai tőkének csak reprezentatív szerepe van.

A budapesti agglomerációs övezetben a külföldi érdekeltségü feldolgozó-ipari vállalkozások jegyzett tőkéje 1997-ben 35,65 milliárd forintra rúgott. A kizárólag külföldi tulajdonú vállalatok jegyzett tőkéje 31,7 milliárd, a vegyes tulajdonú vállalatoké 4 milliárd forint volt. A vegyesvállalatok tőkéjének 77\%-a van külföldi tulajdonban (3,1 milliárd Ft). 1997-ben az övezet feldolgozóiparában jegyzett összes alaptőke 58\%-a külföldi volt, s ez 34 milliárd forintot tett ki. Ez 1\%-kal haladta meg az országos arányt. Biztosra vehetö, hogy a külföldi tőke mennyisége még nagyobb az agglomerációs övezetben, de a Hoppenstedt nem közli például a Tetra Pak, a Tchibo, az SKF, a Kludi, a Schöller-Budatej, a Sony, az Adtranz Dunakeszi MÁV Jármüjavító és a Schlumberger Industries adatait.

A külföldi jegyzett tőke a települések jogállása szerint viszonylag nagy dichotómiát mutatott: a városokban 41, a községekben 59\%-a összpontosult. Az ipar városi koncentrációjának gyengülését mutatja ez az érdekes arány. Hozzá kell tennünk, hogy a városi jogállás - különösen az övezetben - már sok esetben nem 
jelent funkcionális központi szerepet. Sokszor a városok és a községek népessége között sincs számottevő különbség, sőt néhány község lélekszáma nagyobb, mint egyes városoké. Így a városi és községi arányok összevetése csak korlátozottan alkalmazható a feldolgozó-ipari tevékenység hierarchiától függetlenedő terjedésének bemutatására. A külföldi befektetök invesztícióit meghatározó prioritások között a legfontosabb mindenesetre nem a település-hierarchiában elfoglalt hely. Mindez az ipar hierarchikus eloszlását gyengítette. Ez a megállapítás azonban csak gazdasági mikrotereken, dinamikus zónákon belüli viszonyokra igaz. A stagnáló területeken a nagyobb települések vonzóbb célpontok.

A területek közötti eloszlás is azt mutatja, hogy az övezet feldolgozó-ipari térstruktúrájának átrendeződését elsősorban a külföldi tőkeberuházások térbeli eloszlása okozta. A keleti szektorban található a külföldi jegyzett töke közel harmada $(30,4 \%)$. E mikrorégió gazdasági dinamizálódását egyértelmúen a feldolgozóiparban történt külföldi beruházások eredményezték. A következő három térség nagyjából hasonló arányban részesült a külföldi tőkeberuházásokból: a nyugati a külföldi jegyzett tőke 23,3, a déli 20,7, az északi 16,8\%-át tömöríti. A nyugati szektor gazdasága látványos fejlődésének egyik elemét a külföldi tökének köszönhető ipari dinamizálódás alkotja. A szocialista korszak észak-déli irányultságú ipari térszerkezetével szemben (ill. mellett) egy kelet-nyugati bontakozott ki a kilencvenes években, elsösorban a külföldi tökének köszönhetően. Ugyanakkor a hagyományos észak-déli ipari tengely ipari reorganizációjában is tevékeny részt vállalt a külföldi tőke. A délkeleti térség a külföldi töke térszerkezetében fehér folt. Így ez utóbbi terület szakítja csak meg az agglomerációs gyürü egészére jellemzö dinamikát.

\section{TÁBLÁZAT}

A feldolgozó-ipari jegyzett töke megoszlása az agglomerációs övezetben

(The Distribution of Subscribed Capital in the Processing Industry in the Budapest Agglomeration Belt)

\begin{tabular}{crcr}
\hline Terület & Összes & $\begin{array}{c}\text { Vegyes és külföldi } \\
\text { tulajdonú }\end{array}$ & $\begin{array}{c}\text { Tisztán külföldi } \\
\text { tulajdonú }\end{array}$ \\
\cline { 2 - 4 } & \multicolumn{3}{c}{ cégek jegyzett alaptökéje, millió forint } \\
\hline Északi szektor & 10045 & 5742 & 5692 \\
Keleti szektor & 14808 & 11275 & 7265 \\
Délkeleti szektor & 2893 & 122 & 5 \\
Déli szektor & 11274 & 7061 & 5918 \\
Nyugati szektor & 12982 & 8641 & 7325 \\
Északnyugati szektor & 6065 & 3654 & 1722 \\
Az övezet városai & 29060 & 15355 & 10640 \\
Az övezet községei & 29007 & 21050 & 17287 \\
Az övezet & 58067 & 36495 & 27927 \\
\hline
\end{tabular}

Forrás: Hoppenstedt 1999.

Az övezetben a feldolgozóiparban jegyzett külföldi töke részaránya magasabb, mint a hazai tőké részesedése, mintegy 58\%-a az össztőkének. A községekben már 
kétszeresen meghaladja a külföldi jegyzett tőke volumene a hazaiét. A városokban még alatta marad a hazai töke összegének, de nem szignifikánsan (47\%). Biztos, hogy a nem közölt alaptöke adatokkal a városokban is meghaladná a hazai jegyzett tökét. A külföldi jegyzett töke részaránya a keleti szektorban a legmagasabb, $70 \%$. A külföldi jegyzett töke mennyisége a déli, nyugati és az északi területeken is meghaladja a hazait (az össztőke 61, 62 és .57\%-a). Az északnyugati és a délkeleti térségben a hazai tőke még fölényben van. Ez azonban nem a nagyméretủ hazai tőkevolumennek, sokkal inkább a külföldi töke hiányának tudható be.

A Hoppenstedt adatai alapján a külföldi töke jelenléte a feldolgozóiparban 29 agglomerációs településen mutatható ki. 17 településen már fölénybe is került a külföldi töke: a legjobban Szadán, Gyálon, Budakeszin, Törökbálinton, Sződligeten és Dunaharasztin. E települések mindegyike legalább tízszer annyi külföldi, mint hazai tőkét összpontositott. Természetesen a beruházást megelözően jelentéktelen ipari potenciálú településekre történt komoly invesztíció is oka ennek a feltünö aránytalanságnak, de a multinacionális cégek beruházásai az övezeti szinten fontos ipari centrumokban is átbillenthették a mérleg nyelvét: Vácott másfélszer, Gödöllön kétszer nagyobb a külföldi töke nagysága. Néhány régi (Dunakeszi, Szentendre) és újabb keletú (Budaörs, Százhalombatta, Solymár) ipari központban a hazai tőke még örzi fölényét. Ennek oka vagy a jelentősebb külföldi ipari beruházás hiánya (pl. Szigetszentmiklós, Érd, Százhalombatta; bár utóbbi esetében a MOL Rt. köolajfinomítójának adatát figyelembe véve a külföldi tôke fölénye jelentkezne), vagy a hazai tőke viszonylag jelentős tömörülése (pl. Budaörs). Pótlólagos információk beszerzése után valószínűsíthetö, hogy Dunakeszin is nagyobb már a külföldi töke aránya.

\section{A külföldi invesztíciók hatása a tökemozgásokra}

$\mathrm{Az}$ övezetben a külföldi jegyzett tőke matematikai koncentrációja 0,12 , amely meghaladja a jegyzett össztőke és a hazai tőke $(0,08)$ koncentrációját is. Az elméleti koncentrációt pedig tízszeresen múlja felül. A matematikai koncentráció nem fedi teljesen a földrajzi koncentráció fogalmát, föleg jelen esetben, amikor a vizsgált terület nem minden egységében van jelen a vizsgált érték. Így azonos matematikai koncentráció földrajzi térszisztémák több konfigurációját engedi meg.

A 0,12-es koncentráció a földrajzi térben legalább négy gócpontot eredményez: Budaörs térségét, Gödöllő környékét, Vácot és Dunaharasztit. A külföldi tőke legmagasabb koncentrációja a délkeleti, az északi és a déli szektorban figyelhető meg.

$\mathrm{Az}$ északi szektorban Vác, a déliben Dunaharaszti egyeduralkodó a külföldi tőke reprezentációjában (a délkeletiben hasonló Ócsa helyzete, de a kis abszolút mutató csökkenti e tény övezeti térszerkezeti jelentőségét). Vác korábban is hegemón szereppel bírt az ipari térszerkezetben, $\mathrm{s}$ ezt megerősítette a külföldi töke. Dunaharaszti viszont új centrumként emelkedett ki az invesztíciók hatására.

A keletiben és az északnyugatiban már kiegyensúlyozottabb a szerkezet, a leghomogénebb pedig a nyugatiban. A keleti szektorban egy településpár, Gödöllő és 
Szada tömöríti a külföldi tőke túlnyomó többségét. A közepes matematikai koncentráció tényét gyengíti, hogy e két település szomszédos, így a földrajzi térbeli tömörülés erős. Az északnyugati szektorban Szentendre és Pilisvörösvár vezetö pozíciója mellett három kisebb jelentőségü központ emelkedik ki: Solymár, Piliscsaba és Pomáz (koncentráció 0,48 ). Ez a földrajzi térben is átmenetet eredményez a szélsőséges tömbösödés és a teljesen homogén földrajzi térszerkezet között: a fövárossal érintkezö és a nyugati területek felé összeköttetést biztosító részen települt meg a külföldi töke.

A nyugati szektorban már négy hasonló jelentőségü centrum található: Budakeszi, Törökbálint, Budaörs és Zsámbék. A statisztikai homogenitást gyengíti, hogy a földrajzi térben e települések jó része Budapest határán tömörül, s csak Zsámbék képviseli a nyugat felé terjeszkedö folyosót.

A hazai töke koncentrációja több övezeti szektorban is markánsan eltér a külföldi tőkéétől, így az össztőke matematikai koncentrációjának kialakulása a két érték eredőjeként jön létre. A hazai töke koncentrációja a nyugati és az északi szektorban a legnagyobb, a többiben jóval homogénebb. A külföldi tőke koncentrációja különösen a déli, a délkeleti és az északnyugati szektorban haladja meg a hazai töke tömörülését. A nagy külföldi tőkevolumen révén azonban az össztőke koncentrációját csak a déli térségben képes érdemben befolyásolni.

A nyugati területen viszont a külföldi tőke koncentrációja marad jóval alatta a hazai tökéének, s ez döntően befolyásolja az össztőke végül homogén elméleti térszerkezetét. Az északi és kiváltképp a keleti szektorban hasonlóak a koncentrációs adatok, így egyik tőkefajta anomáliája sem volt döntő tényezö az össztőke koncentrációjának kialakulásakor.

Nem mindegy azonban a földrajzi térszerkezet szempontjából, hogy a két tökefajta települése hogyan fedi egymást. Korrelációjuk az övezetben 0,48 ; ez közepes érték. A hazai és külföldi tőke földrajzi elhelyezkedésének korrelációja az északi szektorban volt a legnagyobb, szinte teljesen lefedte a két struktúra egymást. Feltételezve, hogy a hazai tőke térszerkezete a külföldi tőke megjelenésekor hasonló volt, mint jelenleg, a külföldi töke feltünése az ipar térszerkezetében semmilyen módosulást nem eredményezett, maradt a magas koncentrációs szint (Vác hegemóniája). Magas a korreláció az északnyugati térség esetében is, a viszonylag szerény mennyiségü külföldi töke jórészt már meglévő ipari központokba települt. Nagyobb azonban a koncentrációja, s nem mindegyik létező ipari telephelyen jelent meg. Új településeken nem történt beruházás. A külföldi invesztíciók megjelenése tehát tovább fokozta a meglévő központok szerepét.

A keleti szektorban közepes a korreláció, a meglévö ipari központok (Gödöllő) mellett új területeken is megjelent az iparban befektetett külföldi tőke (Szada, Csömör, Veresegyház). Ugyanakkor a korábbi második központban, Pécelen nem történt jelentős tőkeberuházás. A két térszerkezet tehát kevésbé illeszkedik. A külföldi tőke az ipari tevékenység erösödésének térbeli terjedését két irányba befolyásolta: szelektíven hatott a korábbi központokra, és új településeken övezeti szinten jelentős aktivitást gerjesztett. Közepes koncentrációja miatt az iparilag lefedetett terüle- 
tek nagyságát növelte. A fejletlenebb, több válságzónát magában foglaló alföldi és észak-magyarországi régió felé képez egy új modernizációs folyosót.

A déli szektorban a korreláció alacsony a hazai és a külföldi tőke térszerkezete között. Dunaharasztin - egy korábban nem kiemelkedő településen - megjelent multinacionális cég rendkívüli volument és koncentrációt hordoz (igaz egyéb településeken szinte hiányzik a külföldi tőke). Ezzel koncentráltabbá tette az ipar földrajzi térszerkezetét, mivel a recessziótól nagyban sújtott déli térségben jelentös központok számolódtak fel, s ez alacsony matematikai és egyben földrajzi koncentrációt eredményezett. Meg kell azonban jegyeznünk, hogy a MOL Rt. százhalombattai telephelye is jelentős koncentrációt hordoz. Ezt beépítve viszont ellenkező elöjelű hatást vált ki a Dunaharasztin megjelent külföldi tőke - a koncentráció újbóli csökkenését és térbeli kiegyenlítődést.

A nyugati szektorban is igen alacsony a korreláció $(0,3)$. A külföldi töke alacsony koncentrációban, közel hasonló volumennel jelent meg a korábban jelentös (Budaörs) és a kisebb jelentőségủ (Budakeszi, Törökbálint, Zsámbék) ipari településeken, $\mathrm{s}$ ezzel homogénebbé tette az ipar térszerkezetét, csökkentette a statisztikai koncentrációt. A földrajzi tömörülést viszont kevésbé oldotta. Látványos intenzitással néhány csomópontban már összefonódott az észak-dunántúli (pl. Bicske, Esztergom, Dorog) és a budapesti agglomeráció feldolgozó-ipari tere. Délkeleten nem mutatható ki összefüggés a két tőkecsoport településében.

A külföldi töke - amellett, hogy jó része a már meglévő centrumokba települt - új területeket is meghódított.

A külföldi jegyzett tőke település-hierarchikus meghatározottsága (korreláció $0,39)$ jelentősen alatta marad az össztöke és a hazai tőke hasonló mutatójának $(0,54$ ill. 0,6). Ennek a ténynek az az üzenete, hogy a külföldi tőke kevésbé veszi figyelembe a településméretet, $s$ ezzel hozzájárul az ipari tevékenység diffúziójához (feltételezve, hogy a szocializmusban az ipar föként városi illetve központi funkciókat ellátó településeken tömörült, és a városok lélekszáma általánosan nagyobb volt), s az agglomerálódás fokozódásához. Ráadásul, mivel csak a székhely szerinti cégeket elemeztük, ezek a valódi döntési központokat is jelentik, s nem a telephelyek kirajzását. A dekoncentráció mellett és helyett megjelent a decentralizáció. A szektoronkénti helyzet már árnyaltabb képet mutat. A korreláció magas az északnyugati, nyugati és északi szektorban $(0,7$ felett). A keletiben csak közepes érték jelentkezik, a déli és délkeleti térségben szinte semmi összefüggés nincs a településnagyság és a külföldi tőke jelenléte között.

A népességre vetített fajlagos mutatók szintén a községek jelentőségének emelkedését mutatják. A feldolgozóiparban bejegyzett egy főre jutó külföldi alaptőke az övezetben 53,8 ezer forint. Az övezet községeiben és városaiban a populációra vetített külföldi alaptöke között nincs determináns különbség. A községekben 54,7, a városokban 52,6 ezer forint esik egy före. A nem városi jogállású települések felzárkózása egyértelmü. A községek nagy tömegére természetesen még nem jellemző a külföldi tőke jelenléte, a hasonló fajlagos értéket féltucatnyi község magas mutatója okozta. A szektorok vizsgálatakor az abszolút értékekhez hasonló eloszlást 
tapasztaltunk. Két kiugró értékkel találkoztunk, amely több mint kétszeresen felülmúlta az övezeti átlagot. A nyugati szektorban volt a legmagasabb a fajlagos érték, amit a keleti szektor követett. A települések rangsorában Szada került az élre kiugró értékkel (2,1 millió Ft/fö). Ezt követi Dunaharaszti, Zsámbék, Budakeszi, Törökbálint, Gödöllö és Vác; mind 150 ezer forint/fö értékkel. Több község és kisebb település magas mutatója megerősíti a decentralizációról fent elmondottakat.

\section{A külföldi és vegyes tulajdonú cégek bevételének térszerkezete}

A bevétel vizsgálatát azért tartottuk fontosnak, mert - bár eredményességi tartalmat is hordoz - jobban kifejezi a térszerkezetet, mint az alaptöke. A külföldi vagy vegyes tulajdonban lévő feldolgozó-ipari cégek adták az övezetben a szekunder szektor 1997. évi bevételének $60 \%$-át, mintegy 150 milliárd forintot. A tisztán külföldi tulajdonú ipari cégek bevétele 114,3 milliárd forintra rúgott, amely az övezet ipari vállalatai összbevételének $45 \%$-át tette ki. A vegyes és külföldi tulajdonú cégek bevételének $56 \%$-át az övezet városaiban, $44 \%$-át a községekben települt ipari vállalkozások adták. A jegyzett tőkétől eltérően - amely már mind az össztőke, mind a külföldi tőke tekintetében a városok gyengülő szerepét bizonyítja - a bevétel nagyobb része még a városokban elhelyezkedő cégeknél realizálódik, bár a kiegyenlítődés tendenciája egyértelmü. A városok közül a Gödöllőn, Vácott és Budaörsön települt cégek a bevétel 9/10-ét teljesítették. A községek közül Dunaharaszti messze kiemelkedik a községi forgalom több mint harmadával. A sorrendben jövő Veresegyházzal, Szadával, Biatorbággyal és Törökbálinttal a községekben elhelyezkedő vegyes és külföldi tulajdonú ipari cégek forgalmának háromnegyedét tették ki.

A szektorok között messze kiemelkedik a keleti, a bevétel 40,6\%-ával. A sorrendben következö - hasonló nagyságrendü bevételt elérő - déli és nyugati szektorral (20\% körül) az éves bevétel négyötödét koncentrálták.

$\mathrm{Az}$ övezetben a vegyes vagy külföldi tulajdonú ipari cégek bevétele - mint már fentebb jeleztük - meghaladja a hazai cégek forgalmát, bár nem érte el az országos átlagot (70\%). Hasonló a helyzet az övezet városaiban (az összforgalom 56,8\%-a) és községeiben $(57,6 \%$-a) is. A keleti, a déli és a nyugati szektorban szintén a külföldi vagy vegyes tulajdonú cégek fellé billen a mérleg, a keleti szektorban még az országos átlagot is felülmúlja $(77,7 \%)$. Az északiban kiegyenlített arány figyelhetỏ meg, míg a többi térségben a hazai cégek hegemón szereppel bírnak a forgalom alakulásában.

A külföldi vagy vegyes tulajdonban lévő cégek évi bevételének övezeti koncentrációja 0,14 , amely a hazai cégek bevételének 0,06-os koncentrációját több mint kétszeresen múlja felül. Ez természetes, hiszen a külföldi cégek elterjedtsége (föként a bevétel zömét adó multinacionális cégek esetén) - az erösödő diffúzió ellenére - korántsem fedte még le az egész agglomerációs övezetet. A négy csomópont a földrajzi térben a jegyzett tőkéhez hasonlóan a bevétel esetén is jelentkezik. 
A legerösebb koncentráció az északi szektorban található (Vác a földrajzi térben is egyedüli koncentrációt képvisel). Közepes értékek jellemzik a délkeleti, déli és keleti térséget. Földrajzilag mindez a délkeleti és a keleti szektorban egypólusú (Ócsa-Gyál ill. Gödöllỏ környéke), délen kétpólusú (Érd-Diósd-Dunaharaszti) szisztémát alakít ki. A leghomogénebb szerkezet a nyugati és északnyugati szektort jellemzi $(0,27)$. Nyugaton a nagy bevételű települések a föváros és az autópályák mellett csoportosulnak, északnyugaton Budapest határát gyürüszerủen övezik. A hazai cégek bevételének koncentrációja szektoronként 0,18 és 0,48-as érték között mozgott. A két szélsö értéket a déli és az északi szektorban érte el. A külföldi cégek bevételének koncentrációja a nyugati szektor kivételével mindenütt meghaladta a hazai cégek analóg mutatóját. Különösen nagynak mutatkozott a differencia a déli, a délkeleti és az északi térségben. A külföldi tőke az összbevétel koncentrációjának kialakításában érdemben csak az északi és a déli szektorban vett részt, mindkettöben jelentősen növelte a koncentráció mértékét.

A külföldi vagy vegyes tulajdonban lévő vállalatok bevételének a települések nagyságrendjével való korrelációja 0,47 , ami némileg alatta marad az összbevételének. A hazai cégek korrelációja jóval erösebb $(0,6)$ még ma is, amikor már 10 év telt el a centralizált, esetleg dekoncentrált gazdasági szerkezetet favorizáló tervgazdaság bukása, a szerves helyi gazdaság kiépülésének kezdete óta. Ez megerősíti a külföldi beruházásoknak a település-hierarchia és ipari kapacitás kapcsolatát gyengítő, a jegyzett tőke vizsgálatánál már megállapított szerepét. Egyes szektorokban - nyugati, keleti, északi - azonban magas a korreláció, itt a külföldi befektetések zöme a nagyobb és általában iparilag addig is jelentősebb településeket részesítette előnyben. A privatizált vállalatok többnyire a nagyobb településeken helyezkedtek el, így az ily módon megjelenő külföldi tőke eloszlása determináltabb a település-hierarchia áital. A zöldmezös beruházások mozgástere már nagyobb volt, de itt sem mondható el, hogy a településnagyság ne lett volna a beruházások egyik meghatározója.

\section{TÁBLÁZAT}

A feldolgozó-ipari éves bevétel megoszlása a budapesti agglomerációs övezetben (The Distribution of Annual Turnover in the Processing Industry in the Budapest Agglomeration Belt)

\begin{tabular}{lccc}
\hline \multirow{2}{*}{ Terület } & Összesen & $\begin{array}{c}\text { Vegyes és külföldi } \\
\text { tulajdonú }\end{array}$ & $\begin{array}{c}\text { Tisztán külföldi } \\
\text { tulajdonú }\end{array}$ \\
\cline { 2 - 4 } & feldolgozó-ipari cég bevétele 1997 -ben millió forintban \\
\hline Északi szektor & 35936 & 17670 & 16900 \\
Keleti szektor & 78514 & 61024 & 45954 \\
Délkeleti szektor & 6048 & 580 & 150 \\
Déli szektor & 56666 & 31704 & 24219 \\
Nyugati szektor & 50299 & 27391 & 25016 \\
Északnyugati szektor & 25870 & 10818 & 2065 \\
Az övezet városai & 138164 & 80535 & 59940 \\
Az övezet községei & 115167 & 68652 & 54364 \\
Az övezet & 253333 & 149817 & 114304 \\
\hline
\end{tabular}

Forrás: Hoppenstedt 1999. 
A populációra vetített bevétel az abszolút adatok szerkezetéhez hasonló, a városok szerepe azonban még hangsúlyosabb. Az övezetben 244 ezer forint a vegyes és külföldi tulajdonban lévő cégek egy före jutó éves bevétele. A városokban magasabb (314 ezer), mint a községekben (192 ezer). A szektorok rangsorát a keleti és a nyugati vezeti 656 és 408 ezer forintos értékkel. 29 település - ahol jelen van a külföldi töke - közül a vegyes és külföldi tulajdonban lévö cégek egy före jutó éves bevétele főként a keleti szektor néhány településén (Szada, Veresegyház, Gödöllö) és Dunaharasztin éri el a maximum értékeket ( 1 millió forint/fö felett). A nyugati szektor településeinek jelentős része (Biatorbágy, Zsámbék, Budaörs, Törökbálint, Budakeszi), valamint más szektorokból Vác, Diósd, Solymár és Pomáz szintén kiemelkedett, bár kisebb nagyságrendet képviseltek (250-700 ezer Ft/fö). Itt is jelentkezik a kelet-nyugati irány dominanciája.

\section{A külföldi tókeinveszticiók származási helye (a töke, a bevétel és a munkaerö megoszlása)}

A feldolgozóiparban megjelent külföldi tőke országonkénti származási helye nem mutat alapvető eltérést az országos képtől. Az övezetben is - a kumulált adatok alapján - Németország vezet és az USA követi.

\section{1. ÁBRA}

A feldolgozó-ipari külföldi és vegyesvállalatok jegyzett tőkéjének megoszlása származási országonként a budapesti agglomerációs övezetben

(The Distribution of Capital Stock of Foreign Firms and Joint Ventures in the Processing Industry by Countries Taking Part in Investments in the Budapest Agglomeration Belt)

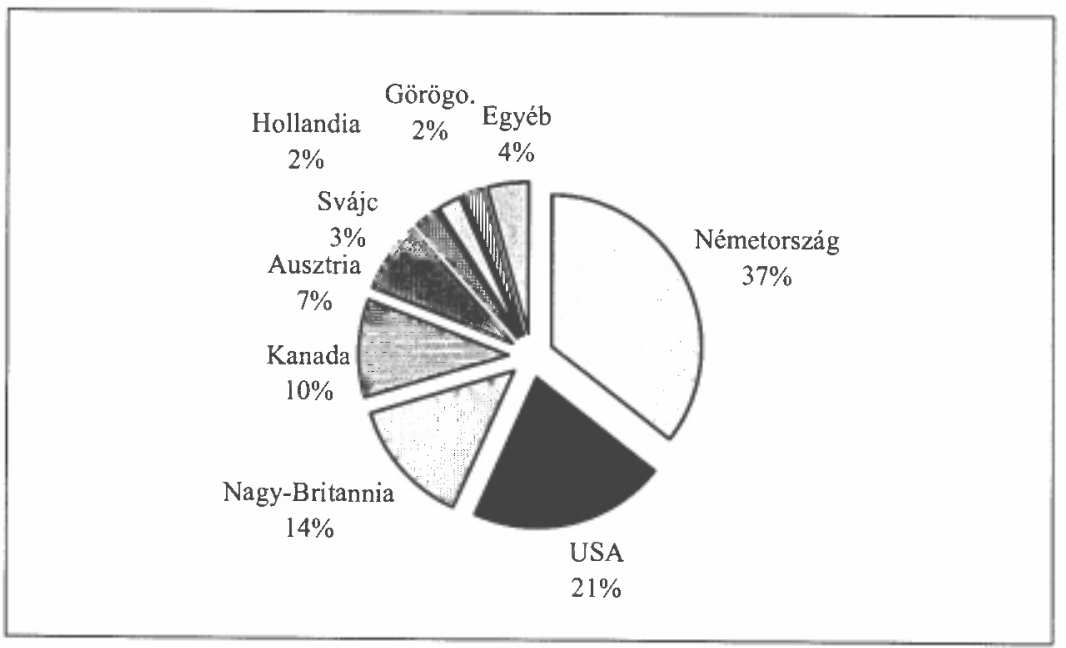

Forrás: Hoppenstedt 1999.

A harmadik legjelentősebb befektető az övezetben azonban nem Ausztria, hanem Nagy-Britannia. Kanada rendkívül masszív jelenléte sem jellemző országosan. Ausztria csak ötödik a rangsorban, képviselete szerényebb, mint az országos. 
Ugyanakkor ez nem jelenti azt, hogy ne lenne meghatározó a jelenléte a budapesti agglomeráció gazdaságában: például a kereskedelmi szektor alaptôkéjének 26\%-át az osztrákok jegyzik. Erősnek tekinthetỏ még a svájci és a holland tétel is. Fentebb említettük, hogy néhány nagyobb külföldi vállalat alaptőke adatát nem közli a Hoppenstedt. E cégek figyelembevételével a japán, a svéd, a holland, a francia és a német befektetések összege nagyobbnak bizonyult volna.

A mintában szereplö külföldi vállalatok országonkénti éves bevétel adatainak vizsgálata különbségeket mutatott az alaptőke adatokhoz képest. A legnagyobb bevételt a második legtöbb tökét befektetö amerikai cégek érték el (mintegy 61,5 milliárd forint, a külföldi érdekeltségủ cégek bevételének $41 \%$-a). Ez nem is meglepő, hiszen az amerikai beruházók jelentős része multinacionális mamutcég (az amerikai érdekeltségű cégek átlagbevétele 8,7 milliárd Ft). Az amerikai cégek bevételeinek átlagtól való eltérése igen nagy. Ennek oka, hogy a globális cégek mellett kisebb vállalatokban is jelen van az USA töke, ezek föként vegyesvállalatok. A legtöbbet befektetó német tulajdonú cégek 35,7 milliárdos bevétele csak a második helyre elég (24\%). A bevételek alapján a német cégek között az európai nagyvállalatoktól a közepes regionális cégeken át kisebb családi vállalkozásokig a teljes méretskála megtalálható. Németországot Ausztria (15 milliárd Ft, 10\%) és Kanada követi $(10,7$ milliárd $\mathrm{Ft}, 7,1 \%)$. Az osztrák cégek méretstruktúrája a némethez hasonló, bár az átlagtól való eltérésük kisebb, mint a német cégeké. A két brit cég egyike közismert multinacionális, a másik európai nagyvállalat. Ezenkívül még egy kanadai és egy svéd cég sorolható a globális cégek közé. Az egyéb európai befektetök már nem érik el ezt a szintet. Plusz információk birtokában feltehetöleg a német, az amerikai, a holland, a japán és a francia cégek bevétele is nagyobbnak bizonyult volna.

\section{2. ÁBRA}

A feldolgozó-ipari külföldi és vegyesvállalatok éves bevételének megoszlása a töke származási országaiként a budapesti agglomerációs övezetben, 1997-ben (The Distribution of Annual Income of Foreign Firms and Joint Ventures by Countries Taking Part in Investments in the Budapest Agglomeration Belt)

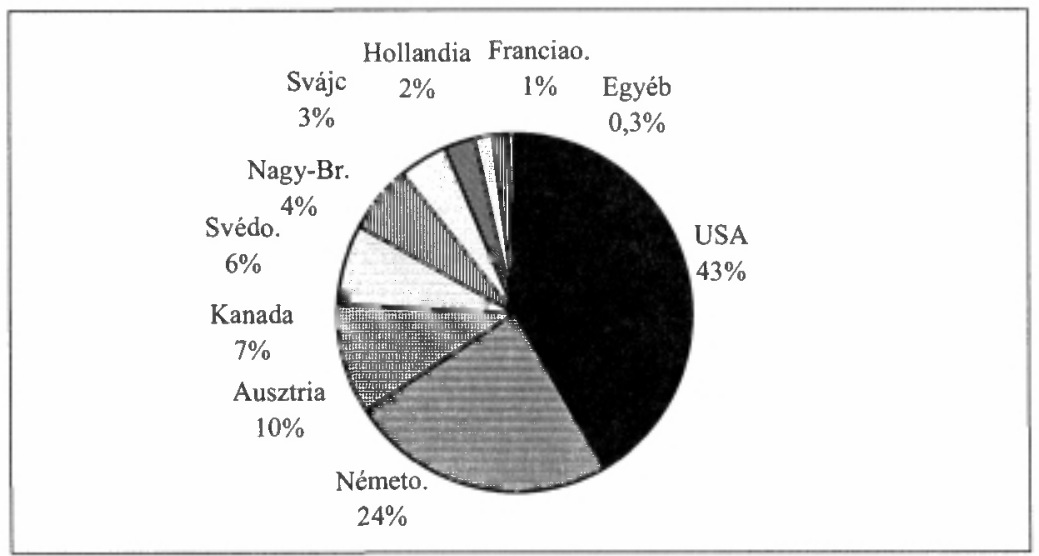

Forrás: Hoppenstedt 1999. 
A minta alapján a befektető országok cégei az övezet ipari munkaerejének harmadát foglalkoztatták. Ezen belül az USA cégei az alkalmazottak 40, a német vállalatok 25 , a franciák 8,2 , a kanadaiak 7,4, az osztrákok 5,8\%-ának biztosítottak kereseti lehetőséget. Az USA a bevételekhez hasonlóan itt is első. Globális cégei foglalkoztatják a legtöbb alkalmazottat. Különösen zöldmezös projektjeik jelentősek, hiszen ezek - országos szinten is - nagy számú új munkahelyet teremtettek. A német cégek, ahhoz képest, hogy mekkora az előnyük a jegyzett tökében, kevesebb munkaerôt alkalmaznak. Munkahelyeik jó része már létezett, hiszen a privatizációban is számottevő szerepet játszottak. A privatizáció után pedig inkább a létszám leépítése, semmint fejlesztése volt napirenden. Hozzá kell tenni, hogy a drasztikus lépéseket ez ügyben általában már nem a külföldi vásárló tette: az elbocsátások nagy része a tranzakció előtt végbement. A dolgozók száma természetesen összefüggésben van az adott iparág munkaerőigényével és a termelőkapacitások áthelyezésének arányával is. Ekképp az országok beruházásainak iparág-specifikussága befolyásolja a munkaerő számát. Az övezetben bejegyzett külföldi cégek egy része - bár telephelyük másutt nincs - nem minden alkalmazottját foglalkoztatja helyben. Jó példa erre a német Schöller és az amerikai Coca-Cola Amatil. A Schöller a 400 alkalmazottból mindössze 180-at, a Coca-Cola 1600-ból kb. 800 föt dolgoztat a cégbejegyzés helyén. A többi munkás az országban elszórtan, elsősorban a kereskedelmi depókban dolgozik.

\section{3. ÁBRA}

A feldolgozó-ipari külföldi és vegyesvállalatok foglalkoztatottjainak megoszlása a töke származási országaiként a budapesti agglomerációs övezetben, 1998-ban (The Distribution of Number of the Employees of Foreign Firms and Joint Ventures in the Processing Industry by Countries Taking Part in Investments in the Budapest Agglomeration Belt)

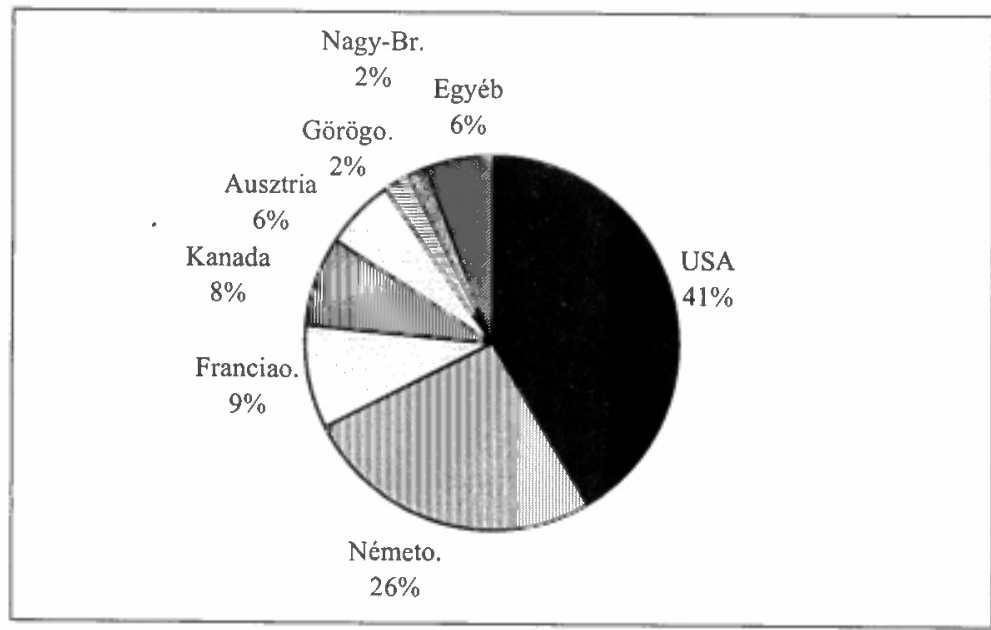

Forrás: Hoppenstedt 1999. 


\section{A zöldmezös beruházások szerepe}

A zöldmezős ipari beruházások rangsorát országos viszonylatban az USA vezeti (41\%) Németország (32\%) és Japán (10\%) elött (a gyárak átköltöztetését figyelmen kívül hagyva). Hasonló arányokkal találkozhatunk az agglomerációs övezetben is. Becsléseink szerint a zöldmezős ipari beruházások jegyzett tőkéit összegezve az Egyesült Államok vezet (7 milliárd forint: pl. Coca-Cola, United Technologies Automative, Avon, Procter \& Gamble); nem sokkal marad le Németország (5,3 milliárd forint: pl. Nordenia) sem. Harmadik Nagy-Britannia (2,1 milliárd forint: pl. Glaxowellcome), negyedik Ausztria (1 milliárd Ft, pl. Schwarzmüller). NagyBritannia helye meglepő, hiszen országosan jelentéktelen a szerepe a zöldmezős ipari beruházásokban. Meg kell jegyeznünk, hogy a Gödöllőn megvalósult SONY beruházást nem állt módunkban figyelembe venni - lévén a Hoppenstedt nem közölte adatait. A SONY adataival a japán zöldmezős beruházás szerépe is jóval jelentősebb lenne. Hasonló a helyzet a holland Tetra Pak-kal. Az övezet iparába került külföldi müködőtőke minimálisan fele zöldmezős beruházásokban öltött alakot. Ez becsléseink szerint meghaladja az országos átlagot, ami érthető, hiszen mára az ipari zöldmezős beruházások egyik központjává vált az agglomerációs övezet.

A zöldmezős beruházásokat illetően különösen a keleti szektor emelkedik ki (Gödöllö térsége), de jelentős a nyugati (Budaörs, Törökbálint) és a déli szektor is (Dunaharaszti). Az amerikai befektetők inkább a keleti térséget részesítették előnyben, de délen valósult meg a legjelentősebb projekt. Az amerikai zöldmezős befektetések mind nagyberuházások, bár legtöbbjük általában az amerikai befektetések méretének alsó határához volt közelebb. A német zöldmezös beruházások legnagyobb tétele szintén a keleti szektorban, Szadán realizálódott, de a kisebb befektető́k föleg a nyugati térségben telepítettek. A brit, svájci, holland, svéd zöldmezős beruházások is a nyugati szektorban tömörültek. A beruházások minden mérete elöfordult körükben. A brit projekteket inkább a nagy méret jellemezte. A minta összes zöldmezős beruházását elemezve a keleten és délen megvalósult projektek átlagos mérete meghaladja a nyugati szektorban jelentkezőt, és volumenük szórása is kisebb.

\section{Összefoglaló gondolatok}

Az 1998-ig beruházott 17 milliárd dollár külföldi töke nagy hatást gyakorolt Magyarország gazdasági térszerkezetére. Ez alól az ipar sem kivétel. A külföldi tökeinvesztíciók területi differenciája a jól ismert okok miatt tovább erösítette a gazdasági erőtérben amúgy is meglévő nagy különbségeket. Ez a régiók, nagyrégiók szintjén mindenképp bizonyítható. A kisebb területeken, mezorégiókban - így az általunk vizsgált budapesti agglomerációs övezetben - nem egyirányúsítható a feldolgozó-ipari térstruktúrára gyakorolt hatása. Megfigyelhető, hogy a befektetések megvalósulásakor fejlettebb területeken kimagasló a töke abszolút mennyisége és a külföldi vállalatok termelési eredményei, jelentős szerepet töltenek be a mun- 
kaeröpiacon. Igazolható hiánya az agglomeráció legelmaradottabb délkeleti területein. Ez a makrorégiók közötti eltérés analógiája. Ugyanakkor megfigyelhettük a tőke megjelenését és eredményeit a relatíve fejletlenebb keleti szektorban, és a kvázi hagyományos ipari válságövezetekben: az északi és a déli térségben. Itt egyértelmü a külföldi tỏke homogenizáló szerepe. Ez a folyamat makroregionális szinten még gyerekcipöben jár.

A külföldi tőke meglehetősen koncentrált megjelenésü. Elsősorban igaz ez a megállapítás a relatíve fejletlenebb területekre. Diffúziója azonban már itt is elindult különösen igaz ez a keleti szektorra - hozzájárulva a fejletlenebb területek felzárkózásához.

A külföldi vállalatok ténykedése oldotta az ipar település-hierarchikus meghatározottságát, városi koncentrációját. A helyi gazdaságok kiépülésével együtt ez szintén a területi különbségek tompulását segítette elö.

A magyarországi új, ma még befejezetlen, dinamikus fejlődési pályájú ipari-kereskedelmi-logisztikai központok sorába (Györ, Székesfehérvár) illeszthető a Budapest-Budaörs-Törökbálint háromszög is. Megfigyelhettük, hogy e centrum kialakításában a külföldi tulajdonú ipari cégek is jelentős szerepet játszottak, még ha a tercier szektor elsősége nem is vitatható. A Gödöllö környékén kibontakozó új magterület alapjának lerakásában viszont elvitathatatlan a feldolgozóipar szerepe. A világgazdaságba való betagozódás magyarországi hordozójaként az ipar újjáéledt, és a „posztindusztriális” korban is számottevő tényező.

\section{Irodalom}

A budapesti agglomeráció. (1998) Budapest, KSH.

A budapesti agglomerációs övezet. (1972) Budapest társadalmának és gazdaságának száz éve. 1872/73_ 1972. Budapest, 237-248. o.

Árva L.-Dicházi B. (1998) Globalizáció avagy a külföldi tökeberuházások hatása Magyarországon. Budapest, Kairosz Kiadó/Növekedéskutató.

Bartha Gy. (1998) Nemzetköziesedés, globalizáció, nemzetközi városok. Budapest. Nemzetközi város. Bartha Gy. (szerk.), Budapest, 13-26. o.

Bartha Gy. (1999) Gazdasági folyamatok a budapesti agglomerációban. Társadalmi-gazdasági átalakulás a budapesti agglomerációban I. - Bartha Gy.-Beluszky P. (szerk.), Budapest, 131-143. o.

Benko, G. (1992) Technológiai parkok és technopoliszok földrajza. Budapest, MTA RKK.

Berényi J.-Somogyi D. (1995) A külföldi müködötőke Magyarországon. - Külgazdaság. 4. 37-56. o.

Budapest kézikönyve. Magyarország megyei kézikönyvei 20. (1998) Budapest, CEBA Kiadó.

Budapesti Statisztikai Évkönyv. (1998) Budapest, KSH.

Enyedi Gy. (1996) Regionális folyamatok Magyarországon. Budapest, Hilscher Rezsö Szociálpolitikai Egyesület.

Hastenberg, H.V. (1999) Foreign direct investment in Hungary: The effects on the modernization of the manufacturing industry and the demand for labor. Utrecht.

Hastenberg, J.J.W.V. (1998) Külföldi nagyvállalatok, multinacionális vállalatok a budapesti iparban. Budapest. Nemzetközi város. - Bartha Gy. (szerk.), Budapest, 83-100. o.

Iván L. (1993) Külföldi tőkeérdekeltségủ vegyesvállalatok létesítésének területi vonatkozásai Magyarországon. - Földrajzi Értesitö. 1-4. 66-77. o.

Kóródi J.-Márton G. (1968) A budapesti és a Pest megyei ipar fejlödésének és fejlesztésnek problémái. A magyar ipar területi kérdései. Budapest, 88-104. o.

Losoncz M. (1996) A gyógyszeripar és az Európai Unió. - Ipargazdasági Szemle. 4. 28-45. o.

Magyarország közép- és nagyvállalatai. (1999) Budapest, Hoppenstedt-Bonnier Kft.

Nagy S. Gy. (1998) A külföldi müködőtőke a budapesti agglomeráció kereskedelmében. Budapest. Nemzetközi város. - Bartha Gy. (szerk.), Budapest, 101-121. o. 
Nagy S. Gy. (1999) Külföldi múködőtőke a budapesti agglomerációban. Társadalmi-gazdasági átalakulás a budapesti agglomerációban I. - Bartha Gy.-Beluszky P.(szerk.), Budapest, 155-165. o.

Nemes Nagy J. (1993) A formálódó piacgazdaság regionalizmusa. Telepúlés, igazgatás, gazdaság a térben. - Kovács K. (szerk.), Pécs, MTA RKK. 203-223. o.

Nemes Nagy J. (1998) A tér a társadalomkutatásban. Budapest, Hilscher Rezsö Szociálpolitikai Egyesület.

Pest megye kezzikönyve. Magyarország megyei kézikönyvei 13. (1998) Budapest, CEBA Kiadó.

Pest Megyei Statisztikai Évkönyv. (1998) Budapest, KSH.

Petruska I. (1996) A versenyképesség és innováció sajátosságai a hazai mủanyagiparban. - Ipargazdasági

Szemle. 1-3. 315-322. o.

\section{THE ROLE OF FOREIGN CAPITAL IN DEVELOPING THE SPATIAL STRUCTURE OF THE PROCESSING INDUSTRY IN THE BUDAPEST AGGLOMERATION BELT}

\section{ZSOLT SÁGI}

Until 199817 billion US dollars has come into Hungary as foreign direct investments (FDI). FDI has had an important influence on the economic spatial structure in Hungary including the processing industry. The territorial disparity of the FDI increased the existent divergence on the economic spatial structure. This phenomenon is provable between the macro-regions. In the smaller territorial units - for example in the examined Budapest agglomeration ring - its effect isn't one-way on the structure of processing industry.

It's obvious, that the quantity of FDI and the output of foreign firms are outstanding in the more developed areas that were already in a better position when the projects had been realized. Foreign firms also have an important role in the local labour market. The lack of FDI is understandable in the most undeveloped south-east sector. This distribution is an analogy of the divergence between the macro-regions.

On the other hand the appearance and effects of the FDI is observable in the moderatelydeveloped eastern sector (the area of Gödöllö) and the traditional industrial micro-regions like the northern and eastern sectors. The territorial equilibrant function of FDI is unambiguous here. This process on the territorial level of the macro-regions has been starting for some years, though it is still in its infancy. The placing of the foreign capital stock is considerably concentrated. This observation is principally real in the relatively undeveloped territories. However the diffusion of the investments has already started - especially in the eastern sector. It contributes to economic development of these underdeveloped areas.

The activity of foreign firms moderate the influence of settlement-hierarchy and city concentration on the capacity of the processing industry.

The Budapest-Budaörs-Törökbálint triangle can be put on the list of dynamic centres with incompleted development (Székesfehérvár, Győr). The foreign firms in the processing industry played an important part on development of this innovation zone, even if the priority of the tertiary industry (the service sector) isn't uncertain. However the foreign companies in the processing industry take upon themselves the bulk of development of a new core area in the Gödöllö micro-region. 